\title{
THE COMPETENCE OF MODERN HIGHER PROFESSIONAL EDUCATION INSTITUTION GRADUATES AS AN OBJECT OF SOCIOLOGICAL REFLECTION
}

\author{
Valentina V. Fursova ${ }^{1}$ \\ Makpal B. Syzdykova ${ }^{2}$ \\ Talant D. Bimakhanov ${ }^{3}$ \\ Maria A. Makhambetova ${ }^{4}$
}

\begin{abstract}
The paper notes that unemployment among young professionals is one of the most important problems in Kazakhstani society. The youth unemployment rate in Kazakhstan is very high. During the economic crisis, youth becomes the most vulnerable group. The level of unemployment among young professionals is almost half of the total unemployment rate in general.The relevance of the chosen research topic lies, first of all, in the increasing share of young specialists in the number of labour force and in the need to develop, in this regard, measures to solve problems associated with the country's youth unemployment. The authors note that the education system does not always form the competencies demanded by students
\end{abstract} in the labour market, as a result of which employers do not want to hire university graduates; they prefer workers having experience, which contributes to the growth of unemployment among university graduates. In this regard, the authors conducted an expert survey of heads of organizations in order to identify their opinions on the competencies of university graduates needed in the labour market (130 people were interviewed). The authors came to the conclusion that the education system does not adequately meet the needs of society as a whole and the economy in particular, and does not fully form the necessary competencies for university students.Recommendations are offered on improving the education system in

\footnotetext{
${ }^{1}$ Kazan Federal University. e-mail: vafursova@yandex.ru

${ }^{2}$ Kazan Federal University. e-mail: vafursova@yandex.ru

${ }^{3}$ Kyzylorda State University named after Korkyt Ata

${ }^{4}$ Kazan Federal University. e-mail: vafursova@yandex.ru
} 
order to form competencies that are important in the modern labour market.

Keywords: youth, university graduates, competencies, employer, competitiveness, unemployment.

\section{Introduction}

Youth unemployment is a socio-economic situation when a young person of working age, ready to perform labour duties, is looking for work, but because of its absence the young person is deprived of the right to work as a source of income. This is the most important characteristic of the situation of youth in society, its adaptability to market relations.

When analysing the labour market, the famous British sociologist J. Goldthorpe introduces the concept of "labour situation" and defines it as a complex of social relations in which "a person is involved at work through his/her position in the division of labour" [2]. The manifestation of the market situation "through a combination of material rewards and life chances" was also considered by R. Erickson [10, p. 176].
380

The social problems of unemployment among young specialists are studied by Ganskau E.Yu., Ponomarenko T.I., Geleta V.I., Akulich M.M., Zaslavskaya T.I., Savinova A.N., Borisova A.A., Kuzmin S.A., Maslova I.S., Vidyapin V.I., Zhuravleva G.P. It was sociologists who mainly drew public attention to the choice of profession as a social problem.

The modern labour market is formed in the process of economic transformation. The indicators of this process are a high level of hidden unemployment; breaking the links between workload and employee income; untimely payment of wages, the gap between the needs of society and prestigious professions, dissatisfaction of employers with the education system, etc. [8, p. 518-522]. The entry of young people into the labour market is accompanied by considerable difficulties and contradictions. The cause of these problems may be related, first of all, to the choice of a profession not because of its demand on the labour market, but in the direction of authority and prestige in society. Therefore, a significant part of graduates do not find work in their specialty or do not find a job at all; this 
leads to increased youth unemployment. As a result, invested finances for their education are not justified. There is also a reluctance of employers to hire university graduates without work experience, because they believe that they lack practical skills and professional competencies. Therefore, the relevance of research is that it is necessary to look for new ways to solve the problem regarding the use of youth labour at the current level of economic development. The research topic is at the junction of a number of pressing problems of modern society, such as the education of workers, the comprehensive development of an individual, the scientific management of society.

\section{Methods}

In order to assess the opinions of employers about the professional training of specialists by the university and further improve the quality of educational services, (October 2018), a survey of the heads of enterprises was conducted. 130 managers of organizations were involved in this survey.

As the analysis of the questionnaires showed, the survey involved respondents employed in various types of professional activity and working in organizations of various organizational and legal forms of entrepreneurship.

\section{Results And Discussion}

The problem of personnel is the most relevant for employers. In the field of professional education, employers have a demand for the most diversified specialists with higher education. The importance of information competence is determined by the transition of Kazakhstani society to the stage of informatisation [9]. This defines new requirements for human resources, including the ability to adapt to the information flow, work with information, perform information loads, and work in an information environment. E.M. Avraamova and Yu.B. Verpakhovskaya in their studies found that employers are primarily interested in the following competencies of graduates: decision-making skills and teamwork, activity, initiative and independence, retraining and training to acquire skills and knowledge. Higher education in the modern labour market is considered as a necessary but 
insufficient condition for employment $[1, \mathrm{p}-38]$.

Personal qualities are also important in the labour market. When hiring a new employee, company managers often take not those who have the appropriate qualifications, but those specialists who differ in their personal qualities. Employees of the recruitment company "Personal" pointed out that, first of all, employers pay attention to the behavioural aspect of the applicant. It should correspond to the corporate culture of the company and have such qualities as ability to work in team, flexibility of thinking, search for nonstandard solutions and stress resistance [7].

According to the results of the survey, it turned out that the very first obstacle to youth employment today is the "lack of work experience"; this factor is important in the life of young graduates. The factor "mismatch of the profession with the desired job" is also an important obstacle for young people. It is known that in our society there are differences in the preferences of young people and the chosen specialties. Due to lack of funds, school graduates cannot get the desired profession, a large number of young people study in specialties for which state grants are allocated. But, they, in turn, don't want to work in their specialty. "Lack of acquaintances" is the third factor hindering youth employment. Note that almost in all our studies, we observed that factors such as the lack of "friends", the lack of "financial capability" always come to the fore. The survey also addressed the problem of "lack of knowledge and qualifications." We explain this factor with the following example. For example, when a young specialist visits workplaces, he/she is asked several questions during an interview. The employer asks, "Do you have any work experience?", "What can you give our company?", "What are you safe for?". This is understandable, that it is beneficial for every employer to get a person who knows the job. Moreover, the big problem is that in the university the applied knowledge in the training of future personnel is not sufficiently developed [5]. Formal student practice causes various problems.

Employers also noted that they are looking for the right workers with the help of numerous resources (through private labour exchanges, through 
advertising in the media, etc.). However, the majority of employers also use methods such as personal and corporate communications, personal acquaintances, offers and advice from close acquaintances when selecting personnel. This is also indicated by the research of Kazakhstan sociologists [4, p-257-262].

Employers also answered questions about their relationship with higher education institutions. For example, we found that only a minimal (about 10\%) number of employers teach author lectures. Some noted that they participate in round tables and conferences held at universities. But it is not observed close professional interaction of employers with universities. Kazakhstani sociologists also write about it. They note that between universities and employers there are no effective relations in the field of research, commercial or scientific novelty [6, p-29-23].

According to the results of a study conducted by Rating.kz research agency with 72 Kazakh and international companies, $64.9 \%$ of respondents said that Kazakh universities do not enter into any contacts with employers in the process of training specialists. According to employers, many higher educational institutions in our country cannot resist competition from near and far abroad. The company's managers and specialists confirmed that Russian universities provide $64.9 \%$ of highquality specialists, followed by British universities (44.4\%) and American universities (36.1\%) [3, p-35-40].

Our study showed that due to the lack of practice and special training, employers do not want to hire youth, namely youth aged 16 to 24 years. The problem is that graduates of educational institutions do not have work experience, and without experience it is impossible to find a job.

As for educational institutions, in our opinion, it is necessary to make certain changes to the curriculum of the university today, that is, introduce special courses aimed at professional, psychological and ethical training of future young specialists, which will overcome difficulties in the process of employment among young people. Such specialized courses allow young professionals to provide comprehensive assistance in finding employment. It is also necessary to make the transition 
from one-time actions for continuous cooperation between enterprises and educational institutions. In the context of the post-industrial economy, it is very important to develop social partnership in the process of training and assessing the quality of education of specialists with higher, secondary and primary education.

\section{Summary}

As the youth employment problems study showed, the existing practice of regulating youth employment is not effective enough. Its improvement is possible in the following directions: a) more clear statement of goals and objectives; b) clarification of its function; c) optimization of the organizational structure; d) more complete justification of regulatory framework and adherence to relevant standards; d) determining the operational composition and the introduction of appropriate process regulations; e) identification and targeted use of the entire set of significant regulatory impacts. In other words, the effectiveness of regulation of youth employment depends on the degree of balance of the entire employment system.

To achieve the appropriate qualities (competencies) among graduates, it is necessary to solve the following problems: 1 . teaching students of practical skills, job search skills, and self-employment. 2. teaching students of self-presentation and interviewing skills. Employers pay attention not only to the red diploma, but to the fact what has been done by a student in the learning process that is interesting and significant for his/her professional development. For this, future specialists need to engage in the development of various projects, participate in contests, grants, and conferences, which will allow developing logical thinking, public speaking skills, and scientific discussion skills. In this regard, it is necessary to make certain changes to the university curriculum today, that is, if special courses of professional, psychological and ethical training of a future young specialist were introduced, then, in our opinion, a number of difficulties in the employment of young specialists could be overcome.

\section{Conclusions}


Currently, many unemployed young people who have graduated from a higher educational institution with a diploma in their hands do not have the opportunity to find work on their own. Newly minted graduates face this difficult problem most of all. If they even find jobs, employers do not accept them without seniority.

Thus, we can recommend the following measures to universities and employers to solve this problem:

1. Allocate more academic hours for practical training in enterprises.

2. Increase the terms of practical training based on the student's training profile.

3. To increase the level of computer literacy, in particular it is better to master the programs MS Excel, MS PowerPoint and all the main application possibilities.

4. To increase the level of knowledge of foreign languages, because a significant part of employers cooperate with foreign companies.

\section{Acknowledgements}

The work is performed according to the Russian Government
Program of Competitive Growth of Kazan Federal University.

\section{References}

Avraamova E.M., Verpakhovskaya Yu.

B. Employers and university graduates in the labour market: mutual expectations // Sociological studies. - 2006.-№ 4. - P. 37-46.

Goldthorpe J. H., Llewellyn C., P. Clive. Social Mobility and Class Structure in Modern Britain. 2nd ed. Oxford: Clarendon Press. 1987.

Ready for work - why not hired? University graduate in a duel with the monster of unemployment // Modern Education. - 2017. - No. 4 (88). - P.3540.

Injigolyan A.A. Labour market fluctuations in the Republic of Kazakhstan: employers' views (based on qualitative research) // "Kazakhstan2050 Strategy: Social Development of the Society": Proceedings of the V Congress of Sociologists in Kazakhstan. - Almaty, 2014. - P.257-262. 
Қазақстандақ жоо түлектерінің жұмысқаапnалалау.Alma mater.

Bulletin of Higher School No. 3, 2016 Zhilyғу Nauryz $/ /$ http://iac.kz/kk/publishing/kazakstandy k-zhoo-tulekterinin-zhumyskaornalasuy.

Maulsharif M., Bolysbaeva S. Zhоғаry оқи oryndarynyң ebekbek naryғуmen ezara orekettesu jəne yleumettik seriktestik құru məseleri // Kazakhstan жоғаry metebi. - 2017. - No. 2. - P.2933.

The official website of the recruitment company "Personal" // http://www.personal.barnaul.ru/? Id_page $=15 \&$ id_razd $=70$.

Shedenova N.U. A sociological analysis of the human capital development of young workers in Kazakhstani companies // Civil Society and Social Progress in the 20th Century. Materials of the second congress of sociologists from Turkic-speaking countries and the third congress of sociologists of Kazakhstan. - Almaty, 2008. - P. 518522.
Fursova, V., Shakirova, A., Nikitina, T., Spirchagova, T., \& Syzdykova, M. (2017). Employment of University Graduates Across the Post-soviet Space: Problems and Solutions (The Example of Kazakhstan). Journal of Culture History and Art Research, 6 (4), 470-478. doi: http:

//dx.doi.org/10.7596/taksad.v6i4.1115

Erikson, R., Goldthorpe J. The Constant Flux: A study of Class Mobility in industrial societies. - Oxford: ClarendonPress, 2012. - P. 176

/I

